\title{
Effect of different dietary energy levels on the reproductive performance of Kivircik sheep under a semi-intensive system in the South-Marmara region of Turkey
}

\author{
M. Koyuncu ${ }^{1}$ and O. Canbolat \\ University of Uludag, Faculty of Agriculture, Department of Animal Science \\ 16059 Bursa, Turkey
}

Received 21 October 2008; revised version 21 July 2009; accepted 6 November 2009)

\begin{abstract}
The objective of the study was to determine the effects of four dietary energy levels $\left(L_{1}-10.3\right.$, $\mathrm{L}_{2}-11.0, \mathrm{~L}_{3}-11.6$ and $\mathrm{L}_{4}-12.2 \mathrm{MJ} \mathrm{ME}$ per $\mathrm{kg} \mathrm{DM}$ ) on oestrus synchronization and fertility in Kivircik ewes. Eighty Kivircik ewes were randomly allocated in equal numbers to the four dietary energy treatments. The groups were treated with intra vaginal sponges containing $40 \mathrm{mg}$ FGA (fluorogestone acetate) for a period of 14 days and 500 IU pregnant mare serum gonadotropin was injected intramuscularly after sponge withdrawal.

The proportion of ewes exhibiting overt oestrus within $96 \mathrm{~h}$ after the injection was significantly lower $(\mathrm{P}<0.05)$ in the $\mathrm{L}_{1}$ and $\mathrm{L}_{2}$ eves $(86$ and $89 \%)$ than in those on the $\mathrm{L}_{3}(100 \%)$ and $\mathrm{L}_{4}(100 \%)$ treatments, respectively. Mean litter size and fecundity were higher $(\mathrm{P}<0.05)$ in the $\mathrm{L}_{3}(1.95)$ and $\mathrm{L}_{4}$ (2.05) compared with the $\mathrm{L}_{1}\left(1.45\right.$ and 1.25) and $\mathrm{L}_{2}(1.63$ and 1.55) ewes. It is concluded that shortterm (21 days) in the level of dietary energy supplementation pre-mating can have a beneficial effect on reproductive performance in ewes.
\end{abstract}

KEY WORDS: sheep, energy, reproduction

\section{INTRODUCTION}

The breeding season of ewes in most parts of the world coincides with the early autumn months. During this period, the reproductive performance of flocks may be

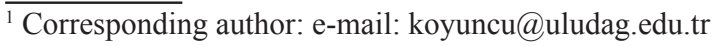


very low in Mediterranean regions because rangelands have dried off potentially limiting both nutrient intake and digestibility of rangeland by ewes (Molle et al., 1997). Under these conditions, protein or energy-based supplementary feeding often referred to as "flushing", around the time of mating improves reproductive performance (Downing et al., 1995; Molle et al., 1995; El-Hag et al., 1998). The role of nutritional flushing should not be ignored, especially where oestrus is included and multiple births are the result. Nutrition has an important impact on the reproductive performance in sheep, but the magnitude of the effect may vary with the season (White et al., 1983). Furthermore, over-feeding can be deleterious to the productivity of ewes (Sormunen-Cristian and Jauhiainen, 2002).

Such nutrient supplementation may be done with feeds high either in energy or in protein, using schemes that vary in timing and duration. In ewes supplemented with $270 \mathrm{~g}$ soyabean meal per ewe per day for 14 days before and 2 days after mating, had fecundity increased by $0.5 / \mathrm{lamb}$ /ewe following a synchronized oestrus (Molle et al., 1997). Increasing energy intake to twice maintenance requirements (Parr et al., 1987) from day 2 to 14 post-mating resulted in a $25-30 \%$ reduction in embryo survival rate. A ration providing proportionately 0.5 estimated metabolizable energy (ME) requirements for maintenance from 2 weeks pre-mating reduced the mean ovulation rate (Rhind et al., 1989) compared with a ration providing proportionately 1.5 estimated ME requirements for maintenance until mating and a restricted ration thereafter or throughout the experimental period (from day 14 before to day 11, 18 or 26 after post-mating). These observations highlight the importance of diet around the time of mating and in particular the significance of over- or under-feeding either pre- or post-mating, in regulating pregnancy rates.

The objective of the present study was, therefore, to investigate the effects of different dietary energy level intakes during pre-mating on reproductive performance in Kivircik ewes when mated at their natural breeding season.

\section{MATERIAL AND METHODS}

The study was conducted at the Department of Animal Science Small Ruminant Research Units, the University of Uludag, Bursa (Turkey). The research units are located on $40^{\circ} \mathrm{N}$ and $29^{\circ} \mathrm{E}$ latitude and longitude, respectively. The area receives on average $700 \mathrm{~mm}$ of rainfall. Mean annual minimum and maximum temperatures experienced at the site are 1.7 and $30.6^{\circ} \mathrm{C}$, respectively.

Eighty Kivircik ewes aged 3-4 years were used during the natural breeding season (autumn). Prior to the trial the animals were maintained on natural pastures. Animals were randomly allocated to four treatment groups and offered concentrate diets that provided different energy levels as MJ ME per kg DM 
$\left(\mathrm{L}_{1}-10.3, \mathrm{~L}_{2}-11.0, \mathrm{~L}_{3}-11.6\right.$ and $\left.\mathrm{L}_{4}-12.2\right)$ and water ad libitum. Treatments were imposed for 21 days of the pre-mating period. The ingredient and chemical composition of concentrate diets are presented in Table 1. During pregnancy the ewes were maintained on rangeland during the day. Hay was fed during the mating and first 4 month of pregnancy at $0.5 \mathrm{~kg}$ per animal per day. All ewes were supplemented daily with 0.3 and $0.4 \mathrm{~kg} / \mathrm{day} / \mathrm{head}$ of concentrates during the last fourth and fifth month of pregnancy, respectively. All ewes were weighed from 21 days before the pre-mating period and after flushing.

Table 1. Ingredient and chemical composition of the concentrate diets, $\%$

\begin{tabular}{|c|c|c|c|c|}
\hline \multirow{2}{*}{ Item } & \multicolumn{4}{|c|}{ Energy level } \\
\hline & $\mathrm{L}_{1}$ & $\mathrm{~L}_{2}$ & $\mathrm{~L}_{3}$ & $\mathrm{~L}_{4}$ \\
\hline \multicolumn{5}{|l|}{ Ingredients } \\
\hline wheat & 44.0 & 54.0 & 64.0 & 74.0 \\
\hline sunflower meal & 24.0 & 24.0 & 24.0 & 24.0 \\
\hline lucerne hay & 30.0 & 20.0 & 10.0 & - \\
\hline limestone & 1.0 & 1.0 & 1.0 & 1.0 \\
\hline salt & 0.9 & 0.9 & 0.9 & 0.9 \\
\hline mineral-vitamin mix. ${ }^{1}$ & 0.1 & 0.1 & 0.1 & 0.1 \\
\hline \multicolumn{5}{|l|}{ Chemical composition of the diet, $\%$} \\
\hline dry matter & 89.40 & 89.49 & 89.58 & 89.65 \\
\hline organic matter & 82.55 & 83.25 & 83.94 & 84.64 \\
\hline crude protein & 16.47 & 16.55 & 16.63 & 16.71 \\
\hline fat & 2.15 & 1.85 & 1.56 & 1.26 \\
\hline crude fibre & 13.33 & 11.20 & 8.00 & 6.95 \\
\hline ash & 6.85 & 6.24 & 5.64 & 5.03 \\
\hline Metabolizable energy, MJ/kg DM & 10.3 & 11.0 & 11.6 & 12.2 \\
\hline
\end{tabular}

Feeding and management practices were applied equally to all ewes. The treatment groups $\left(\mathrm{L}_{1}, \mathrm{~L}_{2}, \mathrm{~L}_{3}\right.$ and $\left.\mathrm{L}_{4}\right)$ were treated with intra-vaginal sponges containing $40 \mathrm{mg}$ FGA (fluorogestone acetate) for a period of 14 days and $500 \mathrm{IU}$ PMSG (pregnant mare serum gonadotrophin) was injected intramuscularly after sponge withdrawal. Oestrus was detected with the aid of an intact-approved ram of proven sexual vigor.

The ewes in oestrus were hand mated twice, at $12 \mathrm{~h}$ after onset of oestrus and $12 \mathrm{~h}$ later with a ram of proven fertility, usually in the morning and evening. Ewes that failed to exhibit oestrus up to 40 days after mating were considered to have conceived and recorded as pregnant. Ewes with newborn lambs were placed in a nursery pen for 2 weeks. Green forage was available continuously in the nursery pen. Lambs were weaned at 60 days.

Data were analysed by ANOVA using the GLM procedure of the statistical analysis system (SAS, 1989); numerical data was analysed by the Chi-square test $\left(x^{2}\right)$ using the PROC FREQ procedure of SAS. 


\section{RESULTS}

Ewes in the low energy $\left(\mathrm{L}_{1}\right)$ treatment gained a mean $2.3 \%$ of initial body weight during the 21-days pre-mating period, these on $\mathrm{L}_{2}, \mathrm{~L}_{3}$ and $\mathrm{L}_{4}$ gained on average 4.5, 7.4 and $10.9 \%$, respectively, during the same period (Table 2). Among the supplemented groups, incremental increases in the energy level of the diet resulted in incremental increases in average weight gain.

Table 2. Mean ( \pm SE) initial body weights prior to flushing and final body weights after 21 days of feeding

\begin{tabular}{lcccccc}
\hline Variable & $\mathrm{L}_{1}$ & $\mathrm{~L}_{2}$ & $\mathrm{~L}_{3}$ & $\mathrm{~L}_{4}$ & SEM & P-value \\
\hline Number of ewes & 20 & 20 & 20 & 20 & & \\
Initial weight, $\mathrm{kg}$ & $55.9 \pm 1.59$ & $56.0 \pm 1.25$ & $55.7 \pm 1.54$ & $55.1 \pm 1.45$ & 4.127 & 0.975 \\
$\begin{array}{l}\text { Final weight, kg } \\
\begin{array}{l}\text { Proportion of weight } \\
\text { change, \% }\end{array}\end{array}$ & $57.2 \pm 1.69$ & $58.5 \pm 1.31$ & $59.8 \pm 1.62$ & $61.1 \pm 1.52$ & 4.946 & 0.940 \\
\hline
\end{tabular}

SEM - standard error of means

More ewes on $\mathrm{L}_{3}$ and $\mathrm{L}_{4}$ exhibited overt signs of oestrus earlier than those in groups $\mathrm{L}_{1}$ and $\mathrm{L}_{2}$. A significantly higher $(\mathrm{P}<0.05)$ proportion of ewes in the $\mathrm{L}_{3}$ and $\mathrm{L}_{4}$ groups 91 and $94 \%$, respectively were bred within $72 \mathrm{~h}$ after rams were introduced compared with 78 and $83 \%$ of $\mathrm{L}_{1}$ and $\mathrm{L}_{2}$ ewes (Table 3).

Table 3. Percentage of ewes bred with time from the time of the second injection of PMSG to the onset of breeding

\begin{tabular}{lllll}
\hline \multirow{2}{*}{ Group } & \multicolumn{4}{c}{ Time from onset breeding, h } \\
\cline { 2 - 5 } & 24 & 48 & 72 & 96 \\
\hline $\mathrm{L}_{1}$ & $19^{\mathrm{a}}$ & $49^{\mathrm{a}}$ & $78^{\mathrm{a}}$ & $86^{\mathrm{a}}$ \\
$\mathrm{L}_{2}$ & $22^{\mathrm{a}}$ & $57^{\mathrm{a}}$ & $83^{\mathrm{a}}$ & $89^{\mathrm{a}}$ \\
$\mathrm{L}_{3}$ & $31^{\mathrm{b}}$ & $68^{\mathrm{b}}$ & $91^{\mathrm{b}}$ & $100^{\mathrm{b}}$ \\
$\mathrm{L}_{4}$ & $36^{\mathrm{b}}$ & $73^{\mathrm{b}}$ & $94^{\mathrm{b}}$ & $100^{\mathrm{b}}$ \\
\hline
\end{tabular}

$\frac{\mathrm{a}, \mathrm{b}}{\mathrm{a}}$ values with different superscripts within column $\operatorname{differ}(\mathrm{P}<0.05)$

Results of conception, lambing and lamb birth weights are shown in Table 4. All ewes on $\mathrm{L}_{1}, \mathrm{~L}_{2}, \mathrm{~L}_{3}$ and $\mathrm{L}_{4}$ were bred during the mating period. The number of ewes lambing within treatment, lambing rates were not different $(\mathrm{P}>0.05)$ among the ewes in all treatments groups. However, ewes on the $\mathrm{L}_{1}$ and $\mathrm{L}_{2}$ treatments had significantly $(\mathrm{P}<0.05)$ lower litter sizes and fecundity responses than those in the other two groups (Table 4). There were no significant differences $(\mathrm{P}>0.05)$ in responses among ewes on $\mathrm{L}_{3}$ and $\mathrm{L}_{4}$ in all parameters tested (Table 4). Different dietary energy levels significantly affected the birth weight of lambs $(\mathrm{P}<0.05)$. 
Table 4. Reproductive performance of Kivircik ewes fed different dietary energy levels

\begin{tabular}{|c|c|c|c|c|c|c|}
\hline \multirow{2}{*}{ Item } & \multicolumn{4}{|c|}{ Group } & \multirow{2}{*}{ SEM } & \multirow{2}{*}{ P-value } \\
\hline & $\mathrm{L}_{1}$ & $\mathrm{~L}_{2}$ & $\mathrm{~L}_{3}$ & $\mathrm{~L}_{4}$ & & \\
\hline \multicolumn{7}{|l|}{ No. of ewes } \\
\hline mated & 20 & 20 & 20 & 20 & & \\
\hline lambing & 17 & 19 & 20 & 20 & & \\
\hline Lambing rate, $\%$ & 85.0 & 95.0 & 100.0 & 100.0 & 2.176 & 0.095 \\
\hline \multicolumn{7}{|l|}{ No. of lambs } \\
\hline singles & 19 & 21 & 18 & 15 & & \\
\hline twins & 6 & 10 & 18 & 20 & & \\
\hline triplets & 0 & 0 & 3 & 6 & & \\
\hline total & 25 & 31 & 39 & 41 & & \\
\hline Litter size $^{\mathrm{c}}$ & $1.47^{\mathrm{b}}$ & $1.63^{\mathrm{b}}$ & $1.95^{\mathrm{a}}$ & $2.05^{\mathrm{a}}$ & 0.054 & 0.047 \\
\hline Fecundity ${ }^{d}$ & $1.25^{\mathrm{b}}$ & $1.55^{\mathrm{b}}$ & $1.95^{\mathrm{a}}$ & $2.05^{\mathrm{a}}$ & 0.060 & 0.038 \\
\hline Lamb birth weight, $\mathrm{kg}$ & $3.2 \pm 0.47^{b}$ & $3.4 \pm 0.83^{\mathrm{b}}$ & $3.8 \pm 0.76^{\mathrm{a}}$ & $4.0 \pm 0.69^{\mathrm{a}}$ & 0.089 & 0.040 \\
\hline
\end{tabular}

different letters $(\mathrm{a}, \mathrm{b})$ within row differ significantly $(\mathrm{P}<0.05){ }^{\mathrm{c}}$ number of lambs born live/ewe lambing; ${ }^{\mathrm{d}}$ number of lambs born live per ewe exposed; SEM - standard error of means

\section{DISCUSSION}

The results of the present study demonstrate that short-term (21-day) changes in dietary energy levels can have a beneficial effect on lambing rate and litter size in ewes. An increase in lambing rate and in the mean litter size of 0.15 percentage points and 0.58 points, respectively, was observed in ewes fed the high-energy diet compared with those fed the low-energy diet for a period of 21 days before mating. This study indicated that restriction of dietary energy intake pre-mating resulted in less body weight gain, delay and suppression of oestrus following synchronization, and reduced litter size. These findings are consistent with the observation that low energy intake adversely affected the lambing rate (Mauraya et al., 2004), delayed the onset of oestrus, lowered the ovulation rate and the incidence of multiple ovulations, and further reduced the pregnancy rate in goats (Mani et al., 1992; Kusina et al., 2001).

Chronic and severe feed restriction has been found to compromise reproductive performance by impairing the hypothalamic gonodotrophin releasing hormone (GnRH) pulse generator (Armstrong and Britt, 1987; Schillo, 1992). Realimentation or flushing is associated with significant increases in systemic luteinizing hormone secretion (Flowers et al., 1988; Booth, 1990) that ultimately restores the ovulation rate. In this study, ewes fed the moderate and high energy diets were receiving adequate or excess dietary requirements, respectively; therefore, their reproductive performance was not compromised, as shown by the high litter size.

The ewes on the low-energy diet $\left(\mathrm{L}_{1}\right)$ had an $8.6 \%$ lower body weight gain 
than those on the high-energy treatment $\left(\mathrm{L}_{4}\right)$, nonetheless $85 \%$ lambed. The lower body weight gain by these ewes indicates that they were in an energy deficit. This is supported by the observation that the ewes fed the low-energy diet were in poor condition at the time of mating. It is possible that Kivircik ewes have adapted to bouts of undernutrition and could mobilize body reserves and successfully ovulate and conceive.

The shorter duration and lower intensity of behavioural oestrus in ewes exposed to nutritional stress has been confirmed by Rhind et al. (1989). It has been established that severe undernutrition inhibits the occurrence of oestrus in ewes (Hafez, 1952). In the present study, the oestrus signs were significantly affected $(\mathrm{P}<0.05)$ by the different dietary energy levels. The underlying mechanism for reduced incidence of oestrus and oestrus duration has not been characterized (Rhind, 1992). However, it has been suggested that ovarian responses are influenced by the availability of nutrients, e.g., glucose and amino acids (Downing et al., 1995). Furthermore, Forcada et al. (1992) reported that oestrus activity and ovulation rate can be stimulated by a moderate to high and constant body condition. Flushing has not always influenced lambing performance (Croker et al., 1985). Since the effect of flushing on liveweight was apparently minimal, it must therefore be assumed that the increased litter size, as suggested by the results of Gunn et al. (1992), was related to an increase in ME intake which affected the ovulation rate directly and not through any increase in body condition.

The reduction in potential lambing rate in low-energy supplemented ewes during pre-mating may be mainly due to energy balance. In fact, it has been reported that low feed intake during pre-mating reduced the mean ovulation rate, and during post-mating, compromised the embryo growth rate and induced a higher rate of ova wastage in sheep (Rhind et al., 1989).

A higher lambing rate may also be the result of the increase in body weight gain of ewes fed the high energy diet at pre-mating. The ability of nutrition to alter the lambing rate of ewes is well known, as a rapid improvement in body weight gain is associated with an increase in ovulation rate and lambing rate (Nottle et al., 1997; Rhind and McNeilly, 1998). In the present study the total body weight gain of ewes fed the high-energy diet at premating was higher than that of ewes fed the low-energy diet. The response to nutritional treatment of animals depends on liveweight, body condition (Nottle et al., 1997; Rhind and McNeilly, 1998), potential reproductive performance and genotype (Abecia et al., 1997; Wilkins, 1997) of the animals, and the actual number of ova released at oestrus is highly dependent on the nature of ewe's long-term nutritional regiments (Nottle et al., 1997). 


\section{CONCLUSIONS}

The results of the present study show that a short-term (3-week) increase in the level of dietary energy during the pre-mating period improved reproductive performance in Kivircik ewes. These results suggest that energy supplementation pre-mating to ewes in autumn can be practiced to improve the reproductive performance of ewes.

\section{REFERENCES}

Abecia J.A., Lozano J.M., Forcada F., Zarazaga L., 1997. Effect of level of dietary energy and protein on embryo survival and progesterone production on day eight of pregnancy in Rasa Aragonessa ewes. Anim. Reprod. Sci. 48, 209-218

Armstrong J.D., Britt J.H., 1987. Nutritional-induced anestrous in gilts: metabolic and endocrine changes associated with cessation and resumption of estrus cycles. J. Anim. Sci. 65, 508-523

Booth P.J., 1990. Metabolic influences on hypothalamic-pituitary ovarian function. J. Reprod. Fertil., Suppl. 40, 89-100

Downing J.A., Joss J., Connell P., Scaramuzzi R.J., 1995. Ovulation rate and the concentration of gonadotropic and metabolic hormones in ewes fed lupin grain. J. Reprod. Fertil. 103, 137-145

El-Hag F.M., Fadlalla B., Elmadih M.A., 1998. Effect on strategic supplementary feeding on ewe productivity under range conditions in north Kordofan, Sudan. Small Ruminant Res. 30, 67-71

Flowers B., Martin M.J., Cantley T.C., Day B.N., 1988. Endocrine changes associated with a dietaryinduced increase in ovulation rate (flushing) in gilts. J. Anim. Sci. 67, 771-778

Forcada F., Abecia J.A., Sierra I., 1992. Seasonal changes in estrus activity and ovulation rate in Rasa Aragoneas ewes maintained at two different body condition levels. Small Ruminant Res. 8, 313-324

Gunn R.G., Milne J.A., Senior Sibbald A.M., 1992. The effect of feeding supplements in the autumn on the reproductive performance of grazing ewes. 1. Feeding fixed amounts of supplement before and during mating. Anim. Prod. 54, 243-248

Hafez E.S.E., 1952. Studies on the breeding season and reproduction of the ewe. J. Agr. Sci. 42, $189-265$

Kusina N.T., Chinuwo T., Hamudikuwanda H., Ndlovu L.R., Muzanenhamo S., 2001. Effect of different dietary energy level intakes on efficiency of estrus synchronization and fertility in Mashona goat does. Small Ruminant Res. 39, 283-288

Mani A.U., McKelvey W.A.C., Watson E.D., 1992. The effects of low levels of feeding on response to synchronization of estrus, ovulation rate and embryo loss in goats. Theriogenology 30, 10161022

Molle G., Baranca A., Ligios S., Sitzia M., Casu S., Landau S., Zoref Z., 1995. Effect of grazing background and flushing supplementation on reproductive performance in Sarda ewes. Small Ruminant Res. 17, 245-254

Molle G., Landau S., Branca A., Sitzia M., Fois N., Ligios S., Casu S., 1997. Flushing with soybean meal can improve reproductive performances in lactating Sarda ewes on a mature pasture. Small Ruminant Res. 24, 157-165

Nottle M.B., Kleemann D.O., Seamark R.F., 1997. Effect of previous undernutrition on the ovulation rate of Merino ewes supplemented with lupin grain. Anim. Reprod. Sci. 49, 29-36 
Parr R., Davis I., Fairclough R., Miles M., 1987. Overfeeding during early pregnancy reduces peripheral progesterone concentration and pregnancy rate in sheep. J. Reprod. Fertil. 80, 317320

Rhind S.M., Mc Kelvey W.A.C., Mc Millen S.R., Gunn R.G., Elston D.A., 1989. Effect of restricted food intake, before and/or after mating, on the reproductive performance of Greyface ewes. Anim. Prod. 48, 149-155

Rhind S.M., 1992. Nutrition: its effects on reproductive performance and its hormonal control in female sheep and goats. In: A.W. Speedy (Editor). Progress in Sheep and Goat Research. CAB International (UK), pp. 25-51

Rhind S.M., Mc Neilly A.S., 1998. Effects of level of feed intake on ovarian follicle number size and steroidogenic capacity in the ewe. Anim. Reprod. Sci. 52, 131-138

SAS, 1989. User's Guide: Statistics. SAS Institute, Inc. Cary, NC

Schillo K.K., 1992. Effect of dietary energy on control of luteinizing hormone secretion in cattle and sheep. J. Anim. Sci. 70, 1271-1282

Sormunen-Cristian R., Jauhiainen L., 2002. Effect of nutritional flushing on the productivity of Finnish landrace ewes. Small Ruminant Res. 43, 75-83

Wilkins J.F., 1997. Method of stimulating ovulation rate in Merino ewes may affect conception but not embryo survival. Anim. Reprod. Sci. 47, 31-42 